University of Nebraska - Lincoln

DigitalCommons@University of Nebraska - Lincoln

\title{
Spatial patterns of cadmium and lead deposition on and adjacent to National Park Service lands in the vicinity of Red Dog Mine,
}

\author{
Alaska \\ L. Hasselbach \\ National Park Service \\ J.M. Ver Hoef \\ Alaska Department of Fish and Game \\ J. Ford \\ Oregon State University \\ P. Neitlich \\ National Park Service \\ E. Crecelius \\ Battelle Marine Sciences Lab \\ See next page for additional authors
}

Follow this and additional works at: https://digitalcommons.unl.edu/natlpark

Part of the Environmental Sciences Commons

Hasselbach, L.; Ver Hoef, J.M.; Ford, J.; Neitlich, P.; Crecelius, E.; Berryman, S.; Wolk, B.; and Bohle, T., "Spatial patterns of cadmium and lead deposition on and adjacent to National Park Service lands in the vicinity of Red Dog Mine, Alaska" (2005). U.S. National Park Service Publications and Papers. 12.

https://digitalcommons.unl.edu/natlpark/12

This Article is brought to you for free and open access by the National Park Service at DigitalCommons@University of Nebraska - Lincoln. It has been accepted for inclusion in U.S. National Park Service Publications and Papers by an authorized administrator of DigitalCommons@University of Nebraska - Lincoln. 


\section{Authors}

L. Hasselbach, J.M. Ver Hoef, J. Ford, P. Neitlich, E. Crecelius, S. Berryman, B. Wolk, and T. Bohle 


\title{
Spatial patterns of cadmium and lead deposition on and adjacent to National Park Service lands in the vicinity of Red Dog Mine, Alaska
}

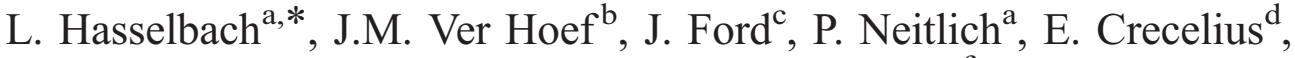 \\ S. Berryman ${ }^{\mathrm{e}}$, B. Wolk ${ }^{\mathrm{e}}$, T. Bohle ${ }^{\mathrm{f}}$ \\ ${ }^{a}$ National Park Service, P.O. Box 1029, Kotzebue, AK 99752, USA \\ ${ }^{\mathrm{b}}$ Alaska Department of Fish and Game, 1300 College Road, Fairbanks, AK 99701, USA \\ ${ }^{\mathrm{c} D e p a r t m e n t}$ of Fisheries and Wildlife, 104 Nash Hall, Oregon State University, Corvallis, OR 97331-3803, USA \\ d Battelle Marine Sciences Lab, 1529 West Sequim Bay Road, Sequim, WA 98382-9099, USA \\ ${ }^{\mathrm{e}}$ Department of Botany and Plant Pathology, Cordley Hall, Oregon State University, Corvallis, OR 97331, USA \\ ${ }^{\mathrm{f}} 252$ Xerxes Street, Minneapolis, MN 55405, USA
}

Received 14 September 2004; received in revised form 17 December 2004; accepted 21 December 2004

Available online 26 April 2005

\begin{abstract}
Heavy metal escapement associated with ore trucks is known to occur along the DeLong Mountain Regional Transportation System (DMTS) haul road corridor in Cape Krusenstern National Monument, northwest Alaska. Heavy metal concentrations in Hylocomium splendens moss $(n=226)$ were used in geostatistical models to predict the extent and pattern of atmospheric deposition of $\mathrm{Cd}$ and $\mathrm{Pb}$ on Monument lands. A stratified grid-based sample design was used with more intensive sampling near mine-related activity areas. Spatial predictions were used to produce maps of concentration patterns, and to estimate the total area in 10 moss concentration categories.

Heavy metal levels in moss were highest immediately adjacent to the DMTS haul road $(\mathrm{Cd}>24 \mathrm{mg} / \mathrm{kg} \mathrm{dw} ; \mathrm{Pb}>900 \mathrm{mg} / \mathrm{kg}$ $\mathrm{dw})$. Spatial regression analyses indicated that heavy metal deposition decreased with the log of distance from the DMTS haul road and the DMTS port site. Analysis of subsurface soil suggested that observed patterns of heavy metal deposition reflected in moss were not attributable to subsurface lithology at the sample points. Further, moss $\mathrm{Pb}$ concentrations throughout the northern half of the study area were high relative to concentrations previously reported from other Arctic Alaska sites. Collectively, these findings indicate the presence of mine-related heavy metal deposition throughout the northern portion of Cape Krusenstern National Monument.

Geospatial analyses suggest that the $\mathrm{Pb}$ depositional area extends $25 \mathrm{~km}$ north of the haul road to the Kisimilot/Iyikrok hills, and possibly beyond. More study is needed to determine whether higher moss heavy metal concentrations in the northernmost portion of the study area reflect deposition from mining-related activities, weathering from mineralized $\mathrm{Pb} / \mathrm{Zn}$ outcrops in the
\end{abstract}

\footnotetext{
* Corresponding author. Tel.: +1 5099963203.

E-mail address: linda_hasselbach@nps.gov (L. Hasselbach).
} 
broader region, or a combination of the two. South of the DMTS haul road, airborne deposition appears to be constrained by the Tahinichok Mountains. Heavy metal levels continue to diminish south of the mountains, reaching a minimum in the southernmost portion of the study area near the Igichuk Hills ( $45 \mathrm{~km}$ from the haul road). The influence of the mine site was not studied.

(C) 2005 Elsevier B.V. All rights reserved.

\section{Introduction}

Cape Krusenstern National Monument is located in a remote region of northwestern Alaska and administered by the National Park Service (NPS). Neighboring Iñupiat village residents use Monument land for subsistence hunting and food-gathering activities. The largest zinc mine in the world, Red Dog Mine, is located approximately $50 \mathrm{~km}$ northeast of the Monument boundary. Since its inception in 1989, Red Dog Mine has operated year-round to produce lead $(\mathrm{Pb})$ and zinc $(\mathrm{Zn})$ concentrates in powder form at the mine site. Ore concentrates are hauled ca. $75 \mathrm{~km}$ in covered trucks via the Delong Mountain Regional Transportation System (DMTS) haul road to storage facilities on the Chukchi Sea, where they are stored for further transport during the short ice-free shipping season.

The DMTS haul road (hereafter referred to as "haul road") traverses $32 \mathrm{~km}$ of Monument land. In 1985, a 100-year transportation easement was granted for construction and use of the haul road through NPS land (Public Law 99-96, 1985). In 2001, NPS researchers reported high concentrations of cadmium $(\mathrm{Cd}>10 \mathrm{mg} / \mathrm{kg}), \mathrm{Pb}(>400 \mathrm{mg} / \mathrm{kg})$, and $\mathrm{Zn}(>1500 \mathrm{mg} / \mathrm{kg})$ in and on Hylocomium splendens moss along the haul road corridor (Ford and Hasselbach, 2001). The source of these high concentrations was attributed to escapement of ore concentrate from trucks and truck surfaces during transport (Ford and Hasselbach, 2001). Sampling was concentrated near the haul road and no attempt was made to determine the extent of the depositional area. These findings formed the basis for the present study, which was designed to estimate the geographic extent and distribution patterns of heavy metal deposition within the Monument.

The NPS is required by law to protect natural and healthy ecosystems (Public Law 96-487, 1980). The ecosystem effects of artificially elevated $\mathrm{Cd}$ and $\mathrm{Pb}$ levels on Monument land are unknown at this time. Mining company consultants are currently conducting an extensive risk assessment effort under the oversight of the State of Alaska Department of Environmental Conservation. Information obtained through the current study will allow focused design of further studies on an appropriate spatial scale. Follow-up research, including determination of potential biological effects, can then be targeted in areas of greatest potential concern.

The use of $H$. splendens in assessing airborne contaminants is well established (e.g., Berg et al., 2003; Rühling and Steinnes, 1998; Berg and Steinnes, 1997; Steinnes, 1995; Steinnes et al., 1992). Mosses lack vascular systems and obtain most of their nutrients from precipitation and from dry deposition of airborne particles (Aberg et al., 2001; Rühling and Steinnes, 1998). Therefore, tissue concentrations are minimally confounded by uptake of mineral elements from soils and subsequent translocation. H. splendens has been particularly well characterized with respect to element uptake (e.g., Rühling and Tyler, 1970), field variability (Ford et al., 1995; Økland et al., 1999), and the relationship between tissue concentration and atmospheric deposition (Berg et al., 2003; Berg and Steinnes, 1997; Ross, 1990).

The goals of this study were: (1) to model the spatial patterns of atmospherically derived $\mathrm{Cd}$ and $\mathrm{Pb}$ deposition in the vicinity of Cape Krusenstern National Monument, (2) to estimate the areal extent of land with moss levels in various concentration categories, and (3) to identify potential sources of these atmospheric heavy metals.

\section{Study area}

Cape Krusenstern National Monument encompasses 266,700 ha bordering the Chukchi Sea approximately $16 \mathrm{~km}$ north of Kotzebue, Alaska 
(Fig. 1). The Monument is located in a tundra ecosystem on a coastal plain with predominantly open, low, mixed shrub-sedge tussock tundra (Viereck et al., 1992) interspersed with low-lying, well-drained knolls supporting a variety of lichen, forb, and shrub species. Bedrock is predominantly calcareous and of Paleozoic age. Soils are poorly developed due to the cold climate, low precipitation, and the near-continuous permafrost.

The haul road bisects the northern portion of the Monument. Immediately south of the haul road, the Tahinichok Mountains are a dominant feature rising from the flat tussock tundra to a maximum elevation of $502 \mathrm{~m}$. South of this mountain range, Monument lands are predominantly wet, flat, and rolling. The area north of the haul road is generally low-laying and gently sloping and drains into the Wulik River approximately $10 \mathrm{~km}$ north of the Monument boundary.

The port facility (Fig. 1) is located on land belonging to NANA Regional Corporation (an Alaska Native corporation) at the western terminus of the haul road. The facility itself is owned by the Alaska Industrial Development and Export Authority which contracts with the mining company, Teck Cominco Alaska, for its use, operation, and maintenance (Exponent, 2002a).

Wind patterns throughout the study area are variable and are influenced by local topography (Exponent, 2002b). Winds at the port site are typically from the northeast in winter months. In summer, port site winds are highly variable and strong winds from the south-southwest are present (Exponent, 2002b). At the mine site, winds are predominantly from the

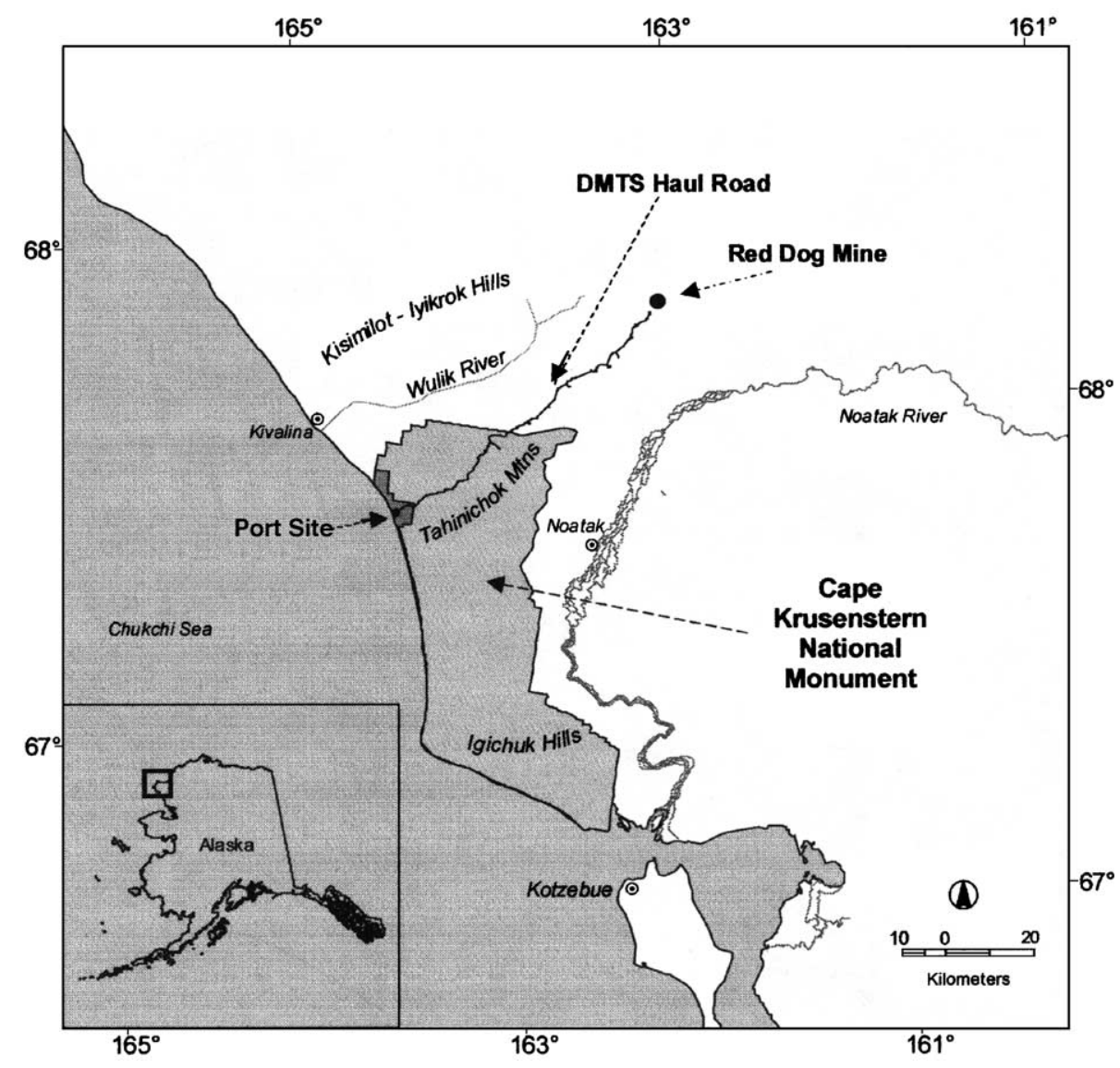

Fig. 1. Location map. Cape Krusenstern National Monument, Alaska. 
northeast and southeast in winter months and highly variable in summer months (Exponent, 2002b).

\section{Methods}

Samples of the $H$. splendens moss and subsurface soil were collected from June through August 2001 in a $5000 \mathrm{~km}^{2}$ area encompassing the Monument and lands to the north (Fig. 2). The study area was centered on the portion of the haul road that crosses Monument lands, and extended approximately $70 \mathrm{~km}$ north and $70 \mathrm{~km}$ south of the road. Laboratory analysis targeted heavy metals of potential toxicological interest $(\mathrm{Cd}$ and $\mathrm{Pb})$. Crustal elements ( $\mathrm{Al}$ and $\mathrm{Fe}$ ) and $\mathrm{Zn}$ were included for interpretive purposes.

\subsection{Sample design}

A stratified, grid-based sample design was used with intensified sampling (i.e., smaller grid cell size) near the haul road and port site boundary. The grid consisted of 8 strata (Table 1; Fig. 2) and a total of 155 grid cells (Table 1). Grid cell size increased gradually (by strata) with distance from the haul road and the port site, allowing for more intensive sampling (i.e., smaller and more numerous grid cells) near these features (Fig. 2). The grid configuration was based on roadside deposition patterns revealed in pilot study data (Ford and Hasselbach, 2001), as well as on time and budgetary considerations.

One primary and several auxiliary sample points were randomly chosen within each grid cell prior to field sampling. If a primary sample point did not contain sufficient Hylocomium (e.g., the sample point fell in a lagoon), an auxiliary point within the same grid cell was located and sampled. Data sheets were completed for all primary points, whether or not moss was present.

A single moss sample was collected at each sampling point. In addition, at $40 \%$ of the points, a second moss sample was collected at a random direction and distance $(<99 \mathrm{~m})$ from the original point to enable estimates of short-range spatial correlations. These samples were referred to as "random duplicates". In 9\% (i.e., 13) of the grid cells, an additional moss collection was also made as close as possible to the original sampling point. These samples were designated as 'field duplicates' and were used to assist in the estimation of variance. Grid cells for collection of random duplicates and field duplicates were randomly selected prior to field sampling.

Mosses were collected on a total of 151 (out of 155) grid cells (Fig. 2; Table 1). The grand total of 226 grid-based moss samples included 13 field duplicate and 62 random duplicate collections.

\subsection{Sample collection}

Moss collection methods were identical to those used in Ford and Hasselbach (2001) and Ford et al. (1995). Unwashed moss samples were picked clean of visible debris (e.g., roots, pebbles) and cropped to include only the most recent (ca. 3-4 years) growth. Specimens were then air-dried on-site in a separate drying tent, sealed, and shipped to the analytical laboratory.

Samples of subsurface soils (mean collection depth $=62 \mathrm{~cm}$ ) were obtained at each primary sample point. At 47 out of 151 points, we were unable to drill deeply enough through permafrost to obtain samples devoid of obvious organic material. Samples at depth that contained conspicuous organic material were not considered representative of soil parent material and were subsequently removed from the sample pool. Due to funding constraints, only a subset of the remaining soil samples was sent for laboratory analysis $(n=46)$. These soils were selected randomly by stratum and were chosen so that all strata were represented (Fig. 2; Table 1). Additional details on soil collection methodology are provided in Ford and Hasselbach (2001).

\subsection{Quality assurance (QA) in the field}

All samples were cleaned, dried in a dedicated drying tent, and packaged for transport at the on-site field laboratory (Fig. 2). To assess ambient levels of heavy metals in the air at the laboratory site (potentially generated by both moss cleaning activity and haul road proximity), four sterile filters were placed in the field laboratory for $24 \mathrm{~h}$ during a typical moss cleaning session. The same protocol was followed in the drying tent. One unexposed blank was also assigned for each session. All filters were 


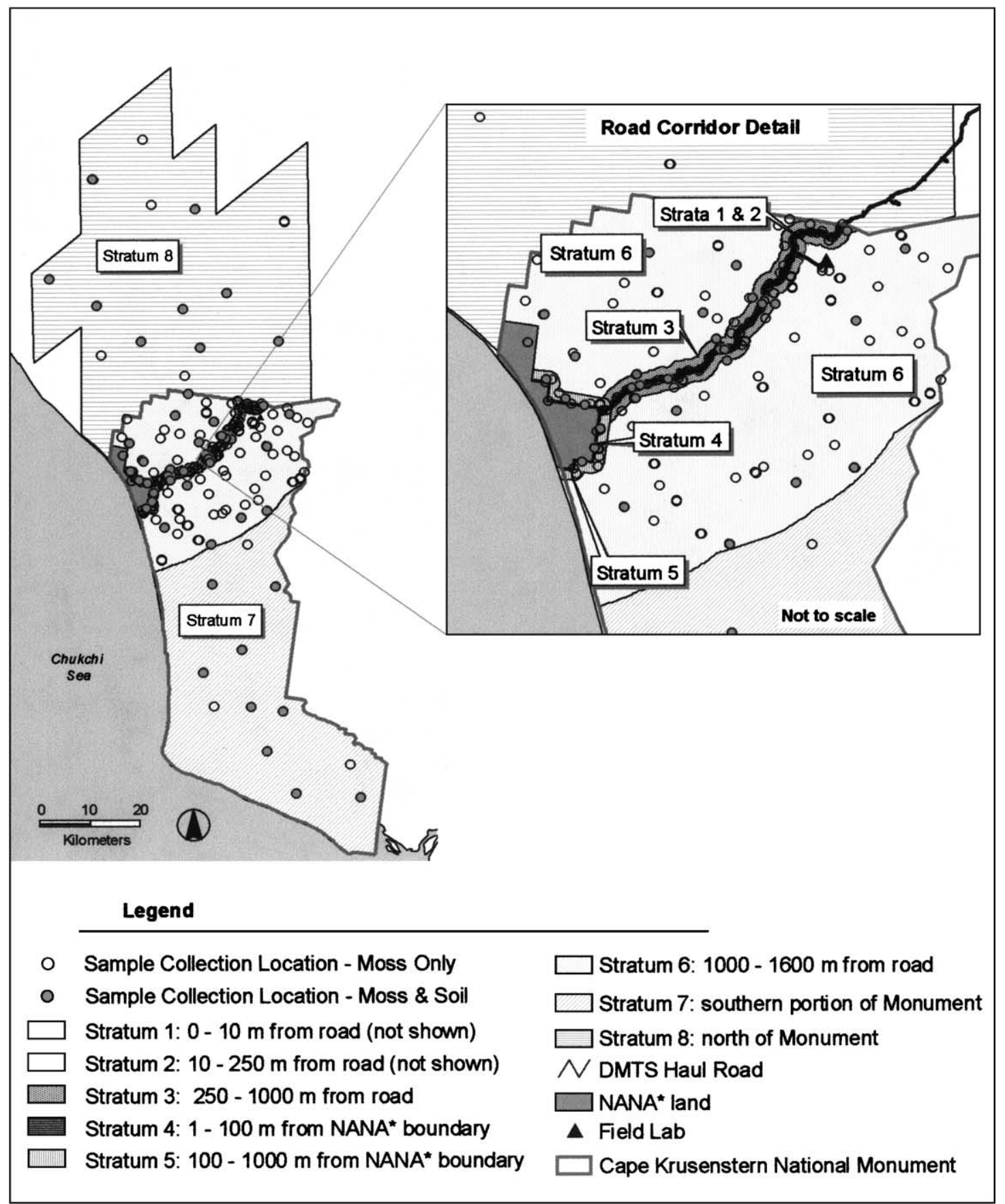

${ }^{\star}$ Northwest Arctic Native Association

Fig. 2. Sample collection locations and strata definition. Mosses were collected and analyzed at each grid cell location ( $n=151)$. Subsurface soil collection locations are shown only for soils used in data analysis $(n=46)$. 
Table 1

The number of points sampled for Hylocomium splendens by strata

\begin{tabular}{|c|c|c|c|c|c|}
\hline Stratum & $\begin{array}{l}\text { Approximate } \\
\text { cell size }\left(\mathrm{km}^{2}\right)\end{array}$ & $\begin{array}{l}\text { Grid cells } \\
\text { sampled }\end{array}$ & $\begin{array}{l}\text { Grid cells } \\
\text { unsampled }^{\text {a }}\end{array}$ & $\begin{array}{l}\text { Total moss } \\
\text { collections }\end{array}$ & $\begin{array}{l}\text { Soil } \\
\text { collections }\end{array}$ \\
\hline 1 & 0.05 & 12 & 0 & 13 & 5 \\
\hline 2 & 1 & 13 & 0 & 15 & 2 \\
\hline 3 & 3 & 18 & 2 & 30 & 1 \\
\hline 4 & 0.20 & 8 & 0 & 9 & 3 \\
\hline 5 & 2 & 8 & 0 & 13 & 3 \\
\hline 6 & 18 & 66 & 1 & 103 & 13 \\
\hline 7 & 200 & 12 & 0 & 19 & 9 \\
\hline 8 & 200 & 14 & 1 & 24 & 10 \\
\hline Totals & & 151 & 4 & 226 & 46 \\
\hline
\end{tabular}

${ }^{\text {a }}$ Not sampled due either to lack of moss or weather-related helicopter constraints.

${ }^{\mathrm{b}}$ Including field duplicate and random duplicate collections.

${ }^{\mathrm{c}}$ Including only the subset of samples used for data analysis.

analyzed for heavy metals and crustal elements. Results showed that elemental content was below the reporting/quantitation of $3.18^{*} \mathrm{MDL}$ (Method Detection Limit), and so laboratory results for moss samples did not require correction for this potential source of contamination.

To verify moss identification and 3-5 year clipping accuracy, blind quality assurance checks were performed by the crew leader on $30 \%$ of all cleaned samples. Vouchers were retained for each moss sample.

\subsection{Laboratory work}

\subsubsection{Moss}

Mosses were not washed as the intent was to study the sum of dry deposition + tissue concentrations (1) to capture the entirety of environmental contributions of heavy metals and (2) to allow comparisons to previous studies. A ca. 300-mg aliquot of each dried sample was combined with nitric, hydrochloric, and hydrofluoric acids in a Teflon bomb and heated overnight in an oven at $130{ }^{\circ} \mathrm{C}\left( \pm 10{ }^{\circ} \mathrm{C}\right)$. Acids were then neutralized with a boric acid solution by heating for four $\mathrm{h}$ at $130{ }^{\circ} \mathrm{C}$ (Shaole et al., 1996). Samples were brought up to volume with deionized water. Aluminum, Fe, and $\mathrm{Zn}$ were analyzed by inductively coupled plasma atomic emission spectrometry (ICP-AES); $\mathrm{Cd}$ and $\mathrm{Pb}$ were analyzed by inductively coupled plasma mass spectrometer (ICPMS). Quality control (QC) samples were run in each batch and included two reagent blanks, two blank spikes, two matrix spikes, and two replicate analyses of field samples. Method detection limits were 5.0 $\mathrm{mg} / \mathrm{kg} \mathrm{dw}$ for $\mathrm{Al}$ and $\mathrm{Fe}, 1.0 \mathrm{mg} / \mathrm{kg}$ dw for $\mathrm{Zn}, 0.5$ for $\mathrm{Pb}$, and 0.05 for $\mathrm{Cd}$. Accuracy was assessed on the high end in each batch with Buffalo River sediment (NIST 2704) to take into account the high dust content of Stratum 1 samples. H. splendens reference material (M2; Steinnes et al., 1997) was obtained from the Finnish Forest Research Institute and run in each batch as well. Standard performance on peach leaves (NIST 1547) was assessed in a separate run. Quality assurance (QA) targets were $\pm 20 \%$; one batch required blank correction for $\mathrm{Cd}$.

\subsubsection{Soils}

A ca. $200 \mathrm{~g}$ aliquot of each dried, homogeneous sample was digested in the same manner as the moss samples, and all elements were analyzed by ICP-MS. QC samples included four reagent blanks, two pairs of matrix spikes, and two replicates analyses of field samples. Method detection limits were $2.0 \mathrm{mg} / \mathrm{kg} \mathrm{dw}$ for $\mathrm{Al}$ and $\mathrm{Fe}, 1.0 \mathrm{mg} / \mathrm{kg} \mathrm{dw}$ for $\mathrm{Zn}$, and $0.02 \mathrm{mg} / \mathrm{kg}$ $\mathrm{dw}$ for $\mathrm{Cd}$ and $\mathrm{Pb}$. Accuracy was assessed using Buffalo River sediment (NIST 2704) and Canadian Research Council reference material sediments BCSS1 and PACS-2. QA targets were $\pm 20 \%$; all batches required blank correction for $\mathrm{Al}$, which was above the method detection limit in reagent blanks but well below concentrations in field samples.

\subsection{Spatial analysis}

Our analysis used a geostatistical spatial model using latitude and longitude for all sample units. To make $x$ - and $y$-coordinates comparable, they were 
according to the Transversal Mercator projection based on a central meridian that was the mean of all of the longitude coordinates of our data. Explanatory variables included distance from haul road, distance from port site, and side of road (i.e., north vs. south). Dependent and distance variables were transformed with the natural logarithm $(\ln )$. To analyze the data $(n=226)$, we used a spatial linear model (e.g., Ver Hoef et al., 2001), with an exponential autocovariance model,

$C_{\theta}(h)=\theta_{1} I(h=0)+\theta_{2} \exp \left(-h / \theta_{3}\right)$

where $h$ is the distance between any two points, $I(a)$ is the indicator function (equal to 1 if the expression $a$ is true, otherwise it is 0 ), and the vector $\theta$ contains three parameters: the nugget $\theta_{1}$, partial sill $\theta_{2}$, and range $\theta_{3}$. Restricted maximum likelihood (REML) was chosen to estimate $\boldsymbol{\theta}$ because ML is known to be more biased than REML (Mardia and Marshall, 1984; Ver Hoef and Cressie, 2001). All regression and covariance parameters were fit using PROC MIXED in SAS. Degrees of freedom used the Satterthwaite option (Satterthwaite, 1941).

Based on a pilot study and exploratory data analysis of bivariate plots, we included haul road, distance from port site, and side of the road (a categorical variable indicating north or south of haul road) and the (distance from haul road $) \times($ distance from port) and (side of road $) \times$ (distance from haul road) interactions in all models. Residuals were checked using $Q-Q$ plots (Wilk and Gnanadesikan, 1968) and appeared to be normally distributed in all cases. Akaike Information Criteria (AIC) (Akaike, 1973) indicated that there was no evidence of anisotropy in the residuals. A spatial version of $R^{2}$ was computed to assess model fit (Hasselbach et al., 2004). There are well-known difficulties in making predictions on the log scale and then back-transforming to the original scale (e.g., Cressie, 1993, p. 136). This is made more difficult by the fact that we have covariates, measurement error, and we wanted to make estimates of complex functions of the predictions (total area above a reference level). Therefore, a Bayesian approach to conditional simulation was used following De Oliveira et al. (1997) for a log transformation and the exponential covariance (2), but using the reference prior described by Berger et al. (2001). Using the three locations measured twice, and an independent data set of 13 samples that the lab measured twice, we developed a posterior inverse $\chi^{2}$ (Gelman et al., 1995, p. 237) for measurement error. We then used this posterior as a prior on $\theta_{\mathrm{ME}}$ for a partitioned nugget effect in (2) so that $\theta_{1}=\theta_{\mathrm{MS}}+\theta_{\mathrm{ME}}$, where $\theta_{\mathrm{ME}}$ is the variance due to measurement error and $\theta_{\mathrm{MS}}$ is the variance due to microscale variation (sensu Cressie, 1993, p. 59). Measurement error was filtered out by letting $\theta_{1}=\theta_{\mathrm{MS}}$ when forming the posterior predictive distribution. Predictions were made on a grid of 6000 cells, where cell size increased with distance from the haul road. A total of 200 simulations were run (on the prediction grid) for each element. The predictions at each location were back transformed from the log scale, and then means over the 200 simulations were used to create interpolation maps. The areal extent of heavy metal deposition was estimated by computing the proportion of the prediction grid values above a given reference level for each simulation in each strata and then multiplying each proportion times the area of the stratum. Quantiles from the 200 simulations provided uncertainty bounds for interpolations and areal estimates.

\subsubsection{Mapping}

Interpolation and contour maps were created from the prediction grid means in ArcView 3.2 (ESRI, 1996) using the inverse distance weighted technique (IDW) with 12 nearest neighbors and power $=2$. Isolines for interpolation maps and categories for estimating areal extent in the 10 moss concentration categories were constructed using a combination of the following objective criteria: (1) quantiles from regional Arctic Alaska moss heavy metal concentration data (Ford et al., 1995) and (2) median heavy metal concentrations from the 'cleanest' stratum (\# 7) within the current study area and their multiples (e.g., $10 \times, 20 \times$, etc.). Subjective intervals based primarily on natural breaks were added where deemed necessary to provide the best graphical representation of spatial patterns, but these were kept to a minimum.

\section{Results}

\subsection{Summary data}

Summary data for analytes in moss and soil across the entire study area are summarized in Table 2 . The 
Table 2

Summary data for analytes in moss and subsurface soil throughout the entire study area, including median, mean, standard deviation (S.D.), and range of values

\begin{tabular}{lllllr}
\hline Substrate $(n)$ & Element & Median & Mean & S.D. & Range \\
\hline Moss $(n=151)$ & $\mathrm{Cd}$ & 0.56 & 1.86 & 3.54 & $0.08-24.30$ \\
& $\mathrm{~Pb}$ & 16.2 & 68.1 & 141.1 & $1.1-912.5$ \\
& $\mathrm{Zn}$ & 92 & 292 & 518 & $2-3207$ \\
& $\mathrm{Al}$ & 773 & 4850 & 10,243 & $46-45,749$ \\
& $\mathrm{Fe}$ & 580 & 3063 & 6242 & $168-28,630$ \\
& & & & 0.13 \\
Soil $(n=46)$ & $\mathrm{Cd}$ & 0.27 & 0.27 & 11.7 & $0.07-0.75$ \\
& $\mathrm{~Pb}$ & 15.3 & 17.8 & 24 & $7.8-83.8$ \\
& $\mathrm{Zn}$ & 96 & 96 & 11,518 & $49-164$ \\
& $\mathrm{Al}$ & 61,350 & 60,760 & 12,559 & $25,900-86,600$ \\
& $\mathrm{Fe}$ & 39,750 & 39,339 & $14,400-71,800$ \\
\hline
\end{tabular}

All units are in $\mathrm{mg} / \mathrm{kg} \mathrm{dw}$.

moss data show a high degree of variability $(2-3$ orders of magnitude) for all elements due to the large differences between areas with greater and lesser heavy metal levels. Log transformation greatly improved the normality of distributions. By contrast, heavy metal concentrations in subsurface soils show relatively low variability.

\subsection{Elemental correlations in moss}

Correlation coefficients were calculated among analytes in $H$. splendens moss (Table 3). Two distinct groups were readily apparent: heavy metals $\left(0.94>r^{2}>0.92\right)$ and crustal elements $\left(r^{2}=0.99\right)$. The three heavy metals $(\mathrm{Cd}, \mathrm{Pb}$, and $\mathrm{Zn})$ are geochemically related and typically co-occur in metal sulfide deposits such as those at the mine site. At Red Dog Mine, $\mathrm{Cd}$ is present in $\mathrm{Pb}$ and $\mathrm{Zn}$ concentrates at levels of approximately $820 \mathrm{ppm}$ $(0.08 \%)$ and $2980 \mathrm{ppm}(0.30 \%)$, respectively (Exponent, 2002a). The crustal elements (Al and

Table 3

All pairwise correlation coefficients among element concentrations in Hylocomium splendens moss $(n=151)$

\begin{tabular}{llllll}
\hline & $\mathrm{Cd}$ & $\mathrm{Pb}$ & $\mathrm{Zn}$ & $\mathrm{Al}$ & $\mathrm{Fe}$ \\
\hline $\mathrm{Cd}$ & 1.00 & 0.94 & 0.94 & 0.79 & 0.79 \\
$\mathrm{~Pb}$ & 0.94 & 1.00 & 0.92 & 0.72 & 0.74 \\
$\mathrm{Zn}$ & 0.94 & 0.92 & 1.00 & 0.77 & 0.79 \\
$\mathrm{Al}$ & 0.79 & 0.72 & 0.77 & 1.00 & 0.99 \\
$\mathrm{Fe}$ & 0.79 & 0.74 & 0.79 & 0.99 & 1.00 \\
\hline
\end{tabular}

All data were $\log _{10}$ transformed.
Fe) exhibited a near 1:1 relationship; $\mathrm{Al}$ is therefore used to represent crustal elements in the analyses that follow. Somewhat weaker correlations $\left(0.79>r^{2}>0.72\right)$ were observed between crustal elements and heavy metals (Table 3 ).

\subsection{Spatial regression}

Spatial regression was used to examine relationships between element concentrations in moss and various factors potentially associated with metal deposition (Table 4). Overall fit of the models was excellent for heavy metals with $R^{2}$ values ranging from 0.83 to 0.86 . The Al model also demonstrated a good fit with an $R^{2}$ value of 0.70 . Several of the independent variables were found to have significant predictive power including (1) distance to the haul road, (2) distance to the port site, and (3) north versus south side of road.

"Distance to the haul road" was significant for all elements $(P<0.001$ for heavy metals $)$ in spatial regression (Table 4). Fig. 3a further illustrates strong road-related gradients encompassing the study area on both sides of the road. These results build upon earlier research (Ford and Hasselbach, 2001) by greatly expanding the known extent of heavy metal escapement from the haul road. Aluminum showed a somewhat weaker relationship with distance to haul road $(P=0.015)$ than was evidenced by the heavy metals.

Concentrations of all three heavy metals in mosses demonstrated statistically significant relationships 
Table 4

Spatial regression results examining relationships between moss concentrations and potential sources of airborne deposition across the entire study area

\begin{tabular}{|c|c|c|c|c|c|c|c|c|c|c|c|c|c|c|c|c|}
\hline \multirow[t]{2}{*}{ Effect } & \multicolumn{4}{|c|}{ Cd model } & \multicolumn{4}{|l|}{$\mathrm{Pb}$ model } & \multicolumn{4}{|l|}{$\mathrm{Zn}$ model } & \multicolumn{4}{|l|}{ Al model } \\
\hline & Estimate & $d f$ & $\mathrm{~F}$ & $P$-value & Estimate & $d f$ & $\mathrm{~F}$ & $P$-value & Estimate & $d f$ & $\mathrm{~F}$ & $P$-value & Estimate & $d f$ & $\mathrm{~F}$ & $P$-value \\
\hline Intercept & 13.12 & 90 & & & 15.79 & 92 & & & 14.42 & 55 & & & 11.41 & 49 & & \\
\hline Side of Road-North & 0.12 & 157 & 0.3 & 0.566 & -0.58 & 50 & 5.6 & 0.022 & -0.22 & 136 & 1.1 & 0.296 & -0.46 & 123 & 1.3 & 0.266 \\
\hline Side of Road-South & 0 & & & & 0 & & & & 0 & & & & 0 & & & \\
\hline Distance to Road & -1.52 & 100 & 55.7 & $<0.001$ & -1.21 & 144 & 18.7 & $<0.001$ & -0.95 & 160 & 18.7 & $<0.001$ & -1.05 & 132 & 6.0 & 0.015 \\
\hline Distance to Port & -1.04 & 88 & 38.1 & $<0.001$ & -0.79 & 97 & 8.8 & 0.004 & -0.50 & 72 & 5.5 & 0.022 & 0.13 & 57 & 0.1 & 0.751 \\
\hline $\begin{array}{l}\text { Distance to Road } \times \\
\text { Side of Road-North }\end{array}$ & 0.05 & 153 & 3.6 & 0.059 & 0.19 & 16 & 23.0 & $<0.001$ & 0.12 & 70 & 9.8 & 0.003 & 0.17 & 61 & 5.9 & 0.018 \\
\hline $\begin{array}{l}\text { Distance to Road } \times \\
\text { Side of Road-South }\end{array}$ & 0 & & & & 0 & & & & 0 & & & & 0 & & & \\
\hline $\begin{array}{l}\text { Distance to Road } \times \\
\text { Distance to Port }\end{array}$ & 0.11 & 98 & 28.4 & $<0.001$ & 0.05 & 138 & 4.0 & 0.048 & 0.04 & 156 & 3.4 & 0.068 & 0.03 & 128 & 0.6 & 0.427 \\
\hline$R^{2}$ & 0.86 & & & & 0.83 & & & & 0.85 & & & & 0.70 & & & \\
\hline
\end{tabular}



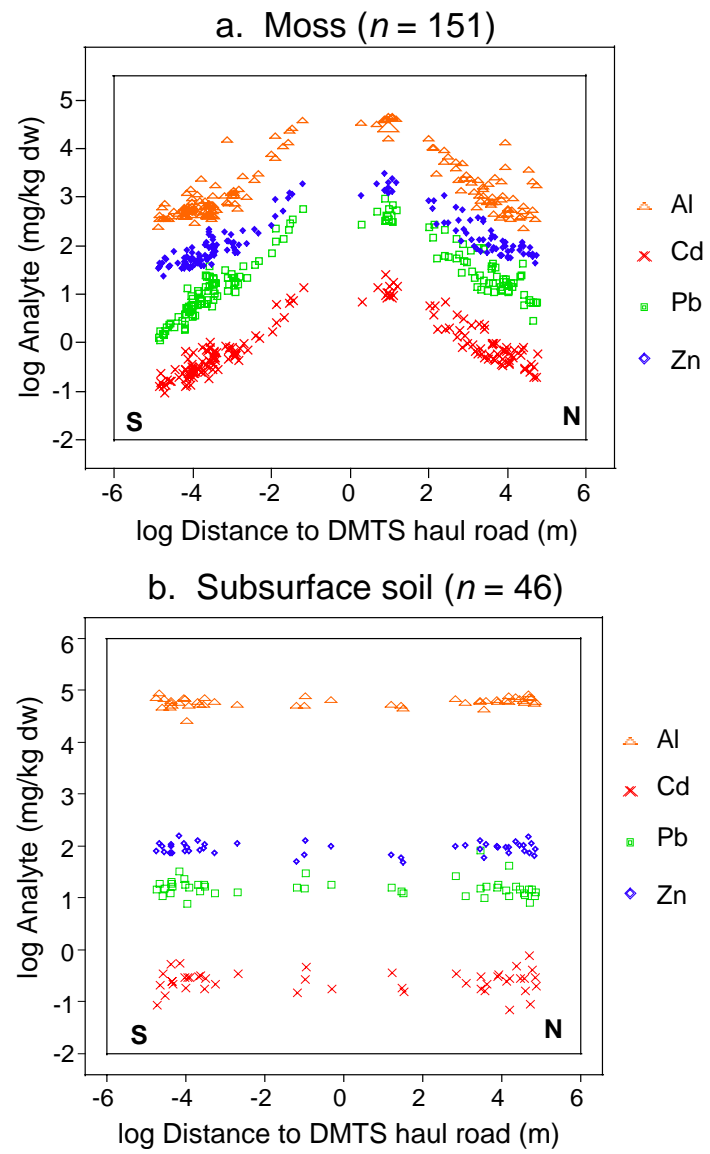

Fig. 3. Elemental concentrations in moss and subsurface soil with respect to the DMTS haul road. The midline of the road is represented by location " 0 " on the X-axis. The south side of haul road is displayed as negative values, whereas the north side of the road is shown as positive. Mean soil depth $=62 \mathrm{~cm}$. All data were $\log _{10}$ transformed.

$(P<0.01)$ with distance to the port site (Table 4). This correlation was not found for $\mathrm{Al}(P=0.751)$. The variable "side of road" (indicating north or south side of the haul road) had significant predictive power in and of itself for $\mathrm{Pb}$ only $(P=0.02)$. However, when entered in spatial regression models as an interaction term with "distance to haul road", it was highly significant $(P<0.01)$ for $\mathrm{Pb}$ and $\mathrm{Zn}$, and nearly significant $(P=0.06)$ for $\mathrm{Cd}$.

\subsection{Patterns of heavy metal deposition}

Spatial patterns estimated by interpolated conditional simulation maps were similar for all elements and consisted of concentric bands of decreasing deposition radiating from the haul road and port site (Figs. 4 and 5).

Mapped patterns depicting strong haul road and port site gradients are consistent with spatial regression results. High levels of heavy metals along the haul road corridor are readily apparent (Figs. 4 and 5). Roadside concentrations (i.e., Stratum 1: 0-10 m from haul road) ranged from 7 to $24 \mathrm{mg} / \mathrm{kg} \mathrm{dw}$ for $\mathrm{Cd}$ and $271-912 \mathrm{mg} / \mathrm{kg} \mathrm{dw}$ for $\mathrm{Pb}$. Highest values (e.g., $\mathrm{Pb}$ legend class: $400-1000 \mathrm{mg} / \mathrm{kg} \mathrm{dw}$ ) occurred along the portion of the haul road nearest to the port site for all analytes (e.g., Fig. 6).

The port gradient itself is displayed as a band of heavy metal deposition around the facility. The pattern is most pronounced to the north-northeast of the facility (Fig. 6). Sampling was conducted along the NPS-NANA port boundary located 3-4 km from the actual port site (Fig. 2). Heavy metal levels in mosses in this area ranged from 20 to $140 \mathrm{mg} / \mathrm{kg} \mathrm{Pb}$ and 0.7 to $3.6 \mathrm{mg} / \mathrm{kg} \mathrm{Cd}$.

Mapped patterns also reveal the differences between heavy metal levels north and south of the haul road detected by spatial regression results (Figs. 4 and 5). In general, moss heavy metal concentrations decrease more gradually with distance on the north side of the haul road than on the south. In the far southern portion of the Monument, metal levels continue to diminish consistently, reaching their lowest levels (median $\mathrm{Cd}=0.16 \mathrm{mg}$ / $\mathrm{kg} \mathrm{dw}$; median $\mathrm{Pb}=2.0 \mathrm{mg} / \mathrm{kg} \mathrm{dw}$ ) in the vicinity of the Igichuk Hills, $40 \mathrm{~km}$ from the haul road. This contrasts with the northern portion of the study area where concentrations remain relatively high $(20-40 \mathrm{mg} / \mathrm{kg} \mathrm{dw} \mathrm{Pb}) 4-40 \mathrm{~km}$ north of the haul road and $\mathrm{Pb}$ levels at the most distant points $(60 \mathrm{~km}$ north of the haul road) are 3-4 times those in the Igichuk Hills in the far southern portion of the study area.

To further investigate depositional patterns north of the haul road, $\mathrm{Pb}$ levels in moss are displayed using both interpolated contour intervals derived from conditional simulation modeling and raw data values (Fig. 7). Results indicate that $\mathrm{Pb}$ levels in Kisimilot/ Iyikrok hills, $25 \mathrm{~km}$ north of the haul road, range from 7 to $42 \mathrm{mg} / \mathrm{kg} \mathrm{dw}$ (Figs. 1 and 7-inset). North of this area, $\mathrm{Pb}$ concentrations decrease to somewhat lower values (ca. $7 \mathrm{mg} / \mathrm{kg} \mathrm{dw}$ ). 


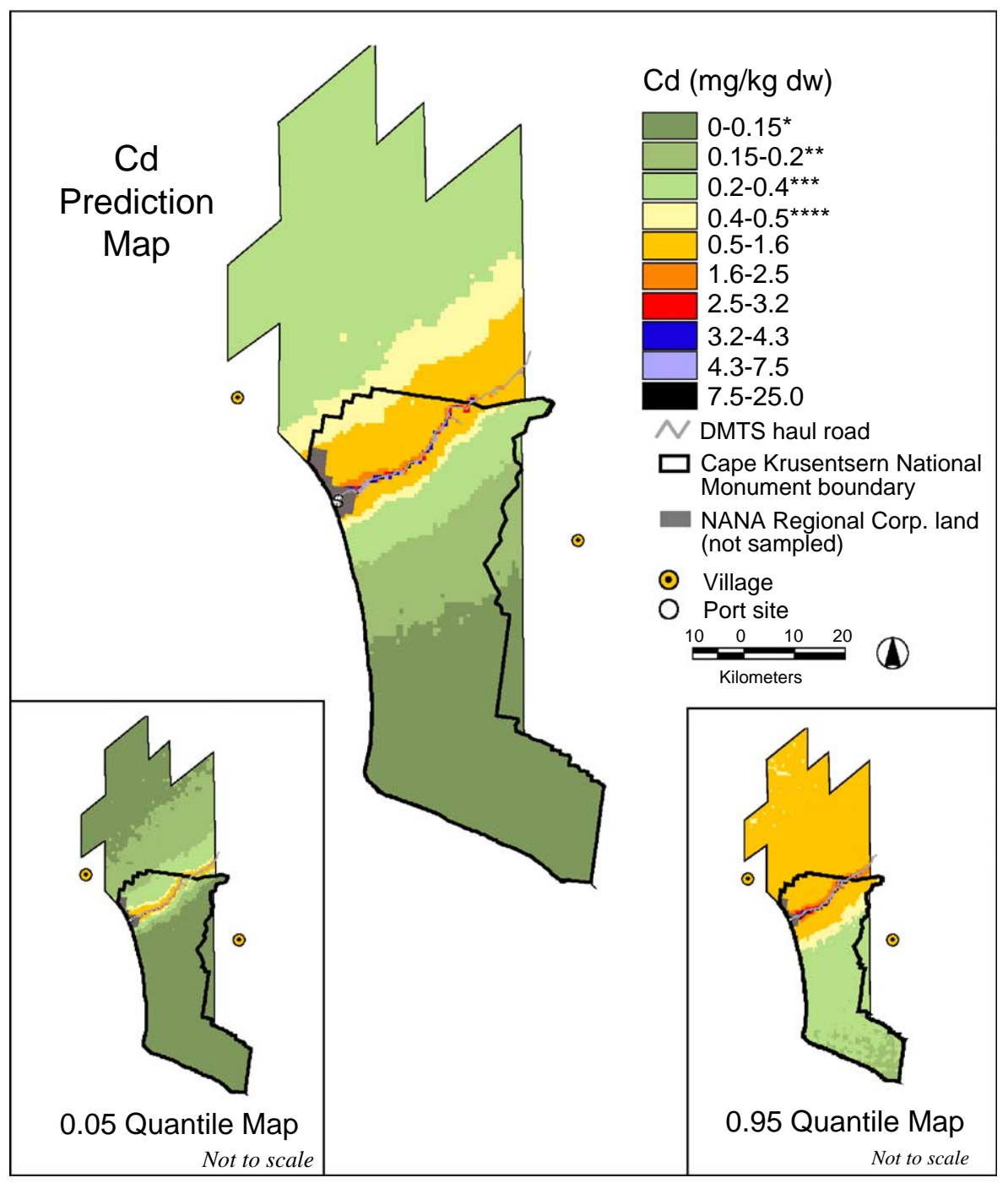

\footnotetext{
* Ford et al. (1995) Arctic Alaska median $=0.15 \mathrm{mg} / \mathrm{kg} \mathrm{dw} \mathrm{Cd}$

** Ford et al. (1995) Arctic Alaska $75^{\text {th }}$ percentile $=0.23 \mathrm{mg} / \mathrm{kg} \mathrm{dw} \mathrm{Cd}$

$* * *$ Ford et al. (1995) Arctic Alaska $90^{\text {th }}$ percentile $=0.41 \mathrm{mg} / \mathrm{kg} \mathrm{dw} \mathrm{Cd}$

**** Ford et al. (1995) Arctic Alaska maximum $=0.48 \mathrm{mg} / \mathrm{kg} \mathrm{dw} \mathrm{Cd}$
}

Fig. 4. Conditional simulation predictions for moss $\mathrm{Cd}$ concentrations in the vicinity of Cape Krusenstern National Monument including 0.05 and 0.95 prediction quantiles.

\subsection{Subsurface soils}

Subsurface soils were analyzed to ascertain whether subsurface geochemistry at the sample points was the underlying cause of the differences observed in moss elemental levels within the study area. Fig. 3b shows that elemental concentrations in subsurface soils are uniform throughout the study area regardless of side of road or distance from haul road. This contrasts with the moss overlay plot in Fig. 3a showing a strong haul road-related gradient. Therefore, higher levels of heavy metals in mosses observed in portions of the study area do not appear to be associated with differences in subsurface geochemistry at the sample points. 


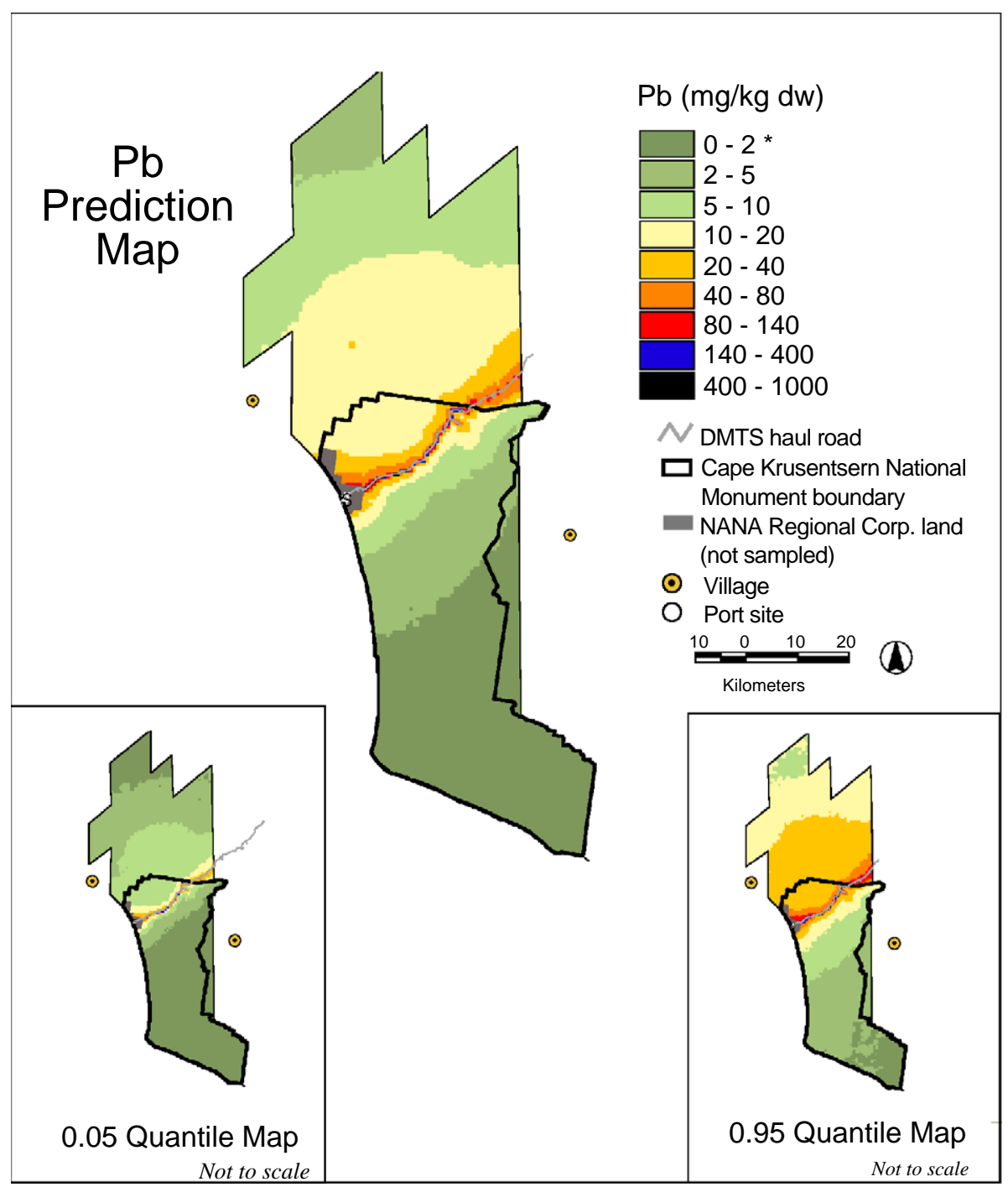

* Ford et al. (1995) Arctic Alaska maximum $=2.3 \mathrm{mg} / \mathrm{kg} \mathrm{dw} \mathrm{Pb}$

Fig. 5. Conditional simulation predictions for moss $\mathrm{Pb}$ tissue concentrations in the vicinity of Cape Krusenstern National Monument including 0.05 and 0.95 prediction quantiles.

\subsection{Regional context}

No site-specific baseline data exist with which to estimate natural, pre-mine surface conditions in and around the Monument. Wiersma et al. (1986) studied heavy metal concentrations in $H$. splendens moss on and near a gravel bar with a long history of motorized air and watercraft use in Noatak National Park. Methods appear to be similar to those used here, although the digestion method is not given. Instead of using just the most recent 3-5 segments, however, these authors used the whole plant, which gives concentrations ca. $2 \times$ those obtained using just the 3-5 distal segments (Ford, unpublished data), probably reflecting accumulation of heavy metals over a longer time frame. Further, there is no indication that moss samples were cleaned of visually obvious debris. The authors of 


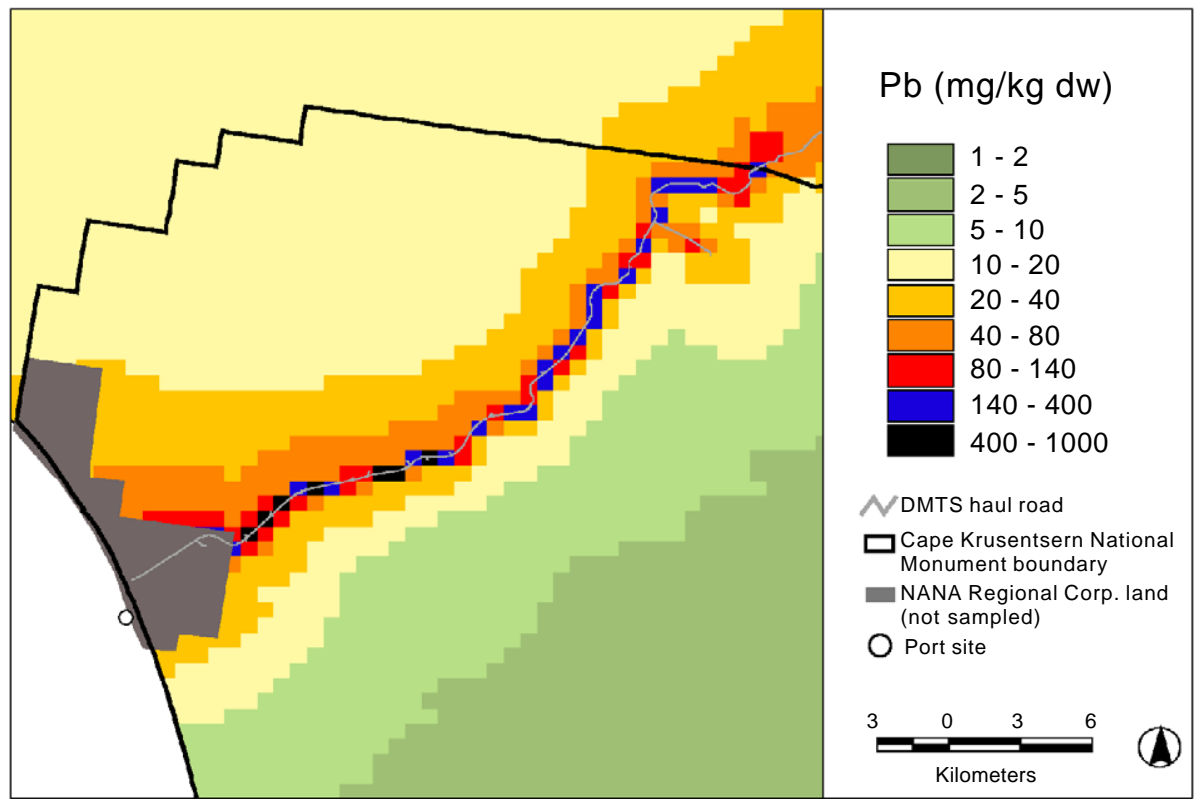

Fig. 6. Conditional simulation predictions for $\mathrm{Pb}$ moss concentrations along the DMTS haul road corridor.

the study considered their $\mathrm{Pb}$ results to be undesirably variable (coefficient of within-site variation ca. 1.2), and $\mathrm{Cd}$ analyses failed accuracy QC checks. For all of these reasons, as well as the fact that the sampling location likely included $\mathrm{Pb}$ deposition from local motorized traffic over several years, the Wiersma et al. (1986) data on $\mathrm{Pb}$ and $\mathrm{Cd}$ are considered unsuitable for comparison with the present study.

A series of $H$. splendens studies was also done by Crock and colleagues for lower latitude regions of Alaska (Crock et al., 1992a,b, 1993). The Denali study is the most pertinent to the current work, although it included intensive sampling near a 25-hp coal-fired power plant. Crock et al. (1992a) note that observed $\mathrm{Pb}$ levels may be associated with this source. Further, the method detection limit for $\mathrm{Cd}$ was relatively high, and most of their $\mathrm{Cd}$ data fell below that value. As in the Wiersma et al. (1986) study, whole moss was used instead of clipping to include just the past 3-5 years. Unlike the present study, mosses in the Crock et al. studies were washed, presumably because dry deposition was not of interest. For all these reasons, the Crock et al. studies are also considered unsuitable for comparison with the present study.
Ford et al. (1995) conducted a regional study of heavy metal concentrations in $H$. splendens moss in Arctic Alaska. That study included three sites located 35-120 km east-northeast of the Red Dog mine site, as well as 10 sites in western Arctic Alaska sampled as part of a pilot grid-based objective sampling campaign. The laboratory and field methods were virtually identical to those used in this study. Therefore, we compare our data for northwestern Alaska to the data in that regional study.

Relative to these regional data, the areas surrounding the haul road and port site contain highly elevated levels of heavy metals (Table 5; Figs. 4 and 5). South of these areas, $\mathrm{Cd}$ levels drop below the maximum concentrations reported by Ford et al. (1995) just north of the crest of the Tahinichok Mountains, $3 \mathrm{~km}$ from the haul road (Figs. 1 and 4). In contrast, $\mathrm{Pb}$ levels do not drop below even the 90th percentile of concentrations reported by Ford et al. (1995) until 40 $\mathrm{km}$ south in the vicinity of the Igichuk Hills (Table 5; Figs. 1 and 5).

To the north, moss Cd levels are between the 75th percentile and the maximum concentrations reported by Ford et al. (1995) (Table 5; Fig. 4). This is in contrast to $\mathrm{Pb}$ levels, which exceed maximum con- 


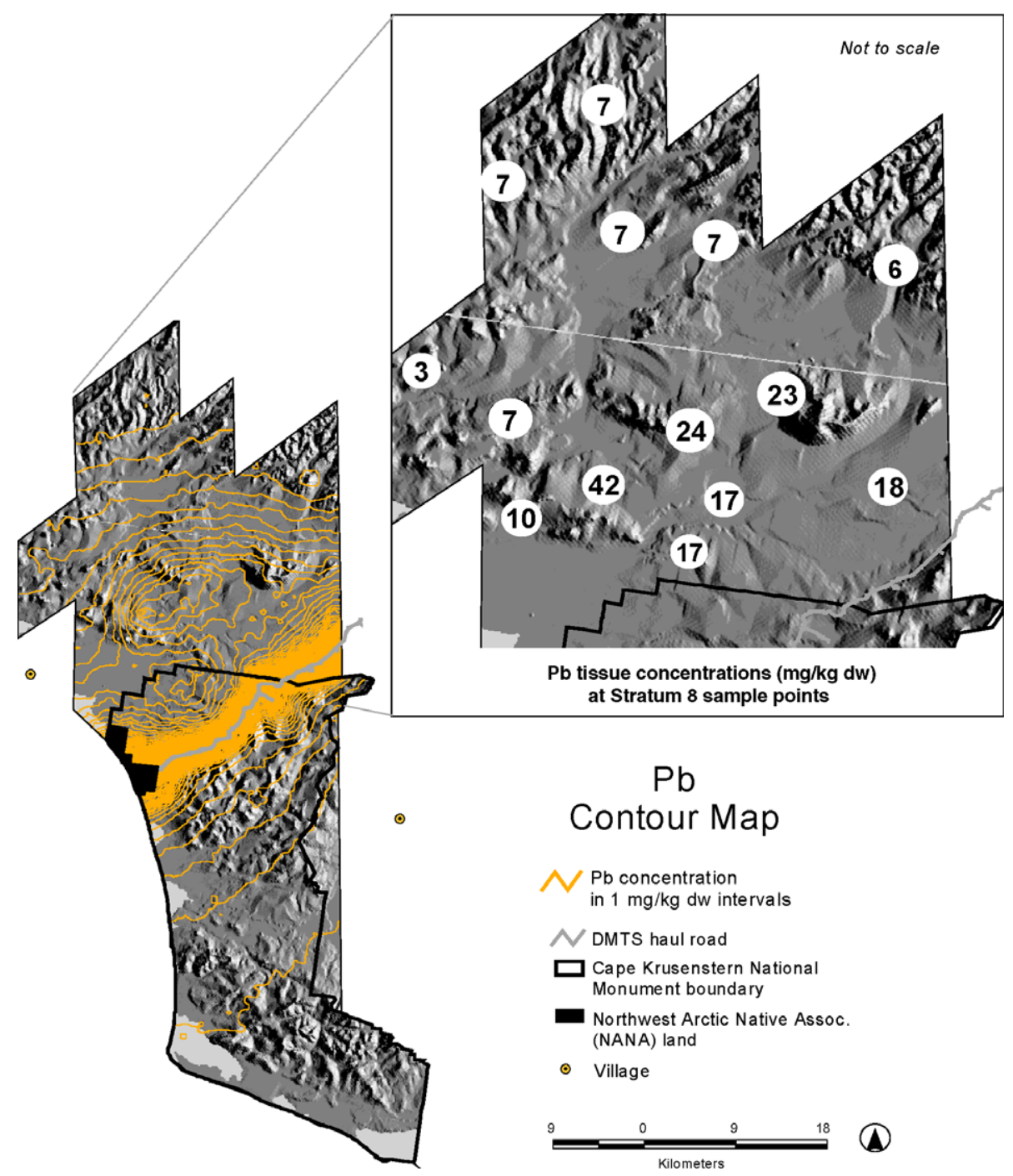

Fig. 7. Moss $\mathrm{Pb}$ concentration contours (derived from conditional simulation) overlain on topography in the vicinity of Cape Krusenstern National Monument. Inlay shows actual $\mathrm{Pb}$ concentrations in the northern portion of the study area. Moss concentrations were rounded for ease of viewing.

centrations reported by Ford et al. (1995) throughout the northern portion of the study area (Table 5; Fig. 5).

\subsection{Geographic extent of deposition}

Conditional simulation estimates were made of the total area for which moss levels fell into various concentration categories (Table 6). In an estimated 90,210 ha, Cd exceeded the maximum concentration for Arctic Alaska reported by Ford et al. (1995)
(Tables 5 and 6). In addition, Cd levels in an estimated 453 ha were greater than $5.0 \mathrm{mg} / \mathrm{kg} \mathrm{dw} \mathrm{Cd}$, or approximately 10 times the maximum concentration reported by Ford et al. (1995) (Tables 5 and 6). For $\mathrm{Pb}$, an estimated 58,067 ha exceeded $20 \mathrm{mg} / \mathrm{kg} \mathrm{dw}$, or approximately 10 times the maximum concentration for Arctic Alaska reported by Ford et al. (1995) (Tables 5 and 6). In addition, approximately 102 ha exceeded $400 \mathrm{mg} / \mathrm{kg} \mathrm{dw} \mathrm{Pb}$ (Table 6). Mosses with the highest heavy metal concentrations were located 
Table 5

Comparison of $\mathrm{Cd}$ concentrations in Hylocomium splendens moss in the current study area with Arctic Alaska values reported by Ford et al. (1995)

\begin{tabular}{|c|c|c|c|c|c|c|c|c|}
\hline & \multicolumn{4}{|l|}{$\mathrm{Cd}$} & \multicolumn{4}{|l|}{$\mathrm{Pb}$} \\
\hline & Median & $\begin{array}{l}\text { 75th } \\
\text { percentile }\end{array}$ & $\begin{array}{l}\text { 90th } \\
\text { percentile }\end{array}$ & Range & Median & $\begin{array}{l}\text { 75th } \\
\text { percentile }\end{array}$ & $\begin{array}{l}\text { 90th } \\
\text { percentile }\end{array}$ & Range \\
\hline \multicolumn{9}{|l|}{ Current study: } \\
\hline$<10 \mathrm{~m}$ from DMTS haul road (Stratum 1) & 11.60 & 14.00 & 21.93 & $6.87-24.31$ & 448.0 & 842.2 & 842.2 & $271.1-912.5$ \\
\hline$>10 \mathrm{~m}$ from DMTS haul road (Strata 2-8) & 0.536 & 0.80 & 2.23 & $0.09-7.98$ & 15.1 & 29.4 & 91.0 & $1.1-350.3$ \\
\hline \multicolumn{9}{|l|}{ Regional data: } \\
\hline Ford et al., 1995 & 0.15 & 0.23 & 0.41 & $0.02-0.48^{\mathrm{a}}$ & 0.6 & 0.8 & 1.4 & $0.4-2.3$ \\
\hline
\end{tabular}

Moss concentration is given as $\mathrm{mg} / \mathrm{kg} \mathrm{dw}$.

a One data point $(\mathrm{Cd}=0.98 \mathrm{mg} / \mathrm{kg} \mathrm{dw})$ was omitted based on problems described by the primary author regarding possible sample contamination during sample transport (J. Ford, personal communication).

along the haul road easement within Cape Krusenstern National Monument (Figs. 4-6).

\section{Discussion}

\subsection{Sources of heavy metal escapement}

Strong depositional gradients exist within our study area with regard to the haul road and port site. Earlier work identified the haul road as an important source of heavy metal escapement (Exponent, 2002a; Ford and Hasselbach, 2001). However, materials used in construction of the haul road did not contain high levels of heavy metals (Exponent, 2002a; Ford and Hasselbach, 2001), and therefore roadbed materials per se were not believed to be a source of heavy metals. Rather, the main mechanism of haul road escapement appeared to be related to the ore trucks (Exponent, 2002a; Ford and Hasselbach, 2001). Ore dust generated in the unloading (and loading) process at the port (and mine) site result in contamination of ore truck surfaces. This fugitive dust is then blown by wind (or washed by rain, etc.) from truck surfaces during transit. Fig. 6 shows heavy metal levels along the haul road diminishing with distance from the port site (see also Exponent, 2002a). A similar escapement mechanism may exist at the mine

Table 6

Conditional simulation estimates of heavy metal depositional areas within the study area and within Cape Krusenstern National Monument (NPS lands)

\begin{tabular}{|c|c|c|c|c|c|}
\hline \multicolumn{2}{|c|}{ Element } & \multicolumn{2}{|c|}{ Entire study area } & \multicolumn{2}{|c|}{ NPS lands only ${ }^{a}$} \\
\hline & $\mathrm{mg} / \mathrm{kg} \mathrm{dw}$ & area (ha) & CI 5-95\% (ha) & area (ha) & CI 5-95\% (ha) \\
\hline \multirow[t]{4}{*}{$\overline{\mathrm{Cd}}$} & $>0.5^{\mathrm{b}}$ & 90,210 & $65,829-119,935$ & 36,594 & $32,574-41,778$ \\
\hline & $>2.0$ & 3592 & $2129-5337$ & 2937 & 2129-3916 \\
\hline & $>5.0$ & 453 & $306-627$ & 450 & $306-627$ \\
\hline & $>8.0$ & 159 & $95-234$ & 159 & $95-234$ \\
\hline \multirow[t]{6}{*}{$\mathrm{Pb}$} & $>2^{\mathrm{c}}$ & 447,374 & $418,653-474,240$ & 175,421 & $150,958-198,890$ \\
\hline & $>20$ & 58,067 & $39,910-85,505$ & 20,538 & $17,172-24,112$ \\
\hline & $>50$ & 10,975 & $4839-11,860$ & 4430 & $3418-5892$ \\
\hline & $>100$ & 2794 & $1032-3912$ & 1368 & $1032-1923$ \\
\hline & $>200$ & 397 & $262-760$ & 360 & $262-476$ \\
\hline & $>400$ & 102 & $66-146$ & 102 & $66-146$ \\
\hline
\end{tabular}

\footnotetext{
Values are presented as overall area estimates in hectares (ha). Confidence intervals (CI) are also given.

${ }^{\text {a }}$ Including road easement.

b Maximum value recorded for Arctic Alaska by Ford et al. (1995) $=0.48 \mathrm{mg} / \mathrm{kg} \mathrm{dw} \mathrm{Cd}$.

${ }^{\mathrm{c}}$ Maximum value recorded for Arctic Alaska by Ford et al. $(1995)=2.3 \mathrm{mg} / \mathrm{kg} \mathrm{dw} \mathrm{Pb}$.
} 
site (Exponent, 2002a), although our sample points were too distant from the mine $(30-100+\mathrm{km})$ to detect such a pattern.

$\mathrm{Up}$ to 1.3 million wet metric tons of $\mathrm{Pb}$ and $\mathrm{Zn}$ concentrate (roughly equivalent to 9 months of mine output) are stored at the port site and subsequently conveyed to barges during the ice-free shipping season (Glavinovich, personal communication, 2004, Exponent, 2002b).

Surface soil $\mathrm{Pb}$ levels in excess of $27,000 \mathrm{mg} / \mathrm{kg}$ $(27 \times$ the U.S. Environmental Protection Agency's industrial soil cleanup standard) were reported near port facility operational areas in a 1996 monitoring summary (Exponent, 2001, 2002c). It is not surprising, then, that our regression results showed significant relationships between distance to the port site and concentrations of all three heavy metals in mosses (Table 4).

The strong relationship between $\mathrm{Cd}$ and distance to the port site merits attention as additional factors may be involved (Table 4). Part of the relationship may be attributable to a maritime effect resulting in higher $\mathrm{Cd}$ in the immediate vicinity of coastlines. For example, analysis of snow samples collected from the Chukchi Sea, the Beaufort Sea, and inland environments has suggested a maritime effect for $\mathrm{Cd}$ (Garbarino et al., 2002). In the current study, the relationship between $\mathrm{Cd}$ and distance to the port site may not be fully separable from the relationship with distance to the sea. Further, Ford et al. (1995) found variable $\mathrm{Cd}$ concentrations in inland Arctic Alaskan samples of $H$. splendens moss that were not explained by either slope position or associated vegetation type. These authors suggested that a combination of factors "combining lithological sources with landscape setting and hydrological factors" play a role in determining moss $\mathrm{Cd}$ concentrations in pristine environments. Though both distance to port site and distance to the haul road are certainly major explanatory variables for gross spatial patterns of $\mathrm{Cd}$ concentrations, more work is required to understand finer scale variation of $\mathrm{Cd}$ in the study area and the region.

\subsection{Heavy metals and dust}

There are both similarities and differences between distribution of heavy metals $(\mathrm{Cd}, \mathrm{Pb}$, and
$\mathrm{Zn})$ and the crustal elements present in dust (Al). Both show significant relationships with distance to the haul road, although the relationship is weaker for Al than for heavy metals $(P=0.015$ vs. $P<0.001$ ) (Table 4). The relationships with the port site are quite different, however, with $\mathrm{Al}$ demonstrating a distinct lack of relationship to distance to the port site (Table 4). This is probably due to the fact that traffic slows considerably in the vicinity of the port site, thereby mobilizing less dust and weakening the "dust signal" from that area.

Although strong correlations were observed between the heavy metal group and crustal element group, within-group correlations were found to be somewhat stronger than between-group correlations (Table 3). This is likely because sources of the two groups of elements, although related in many ways, also include independent contributions. For example, as discussed above, heavy metal escapement along the haul road corridor has been attributed to windblown dispersal of concentrate from ore truck surfaces. Vehicles other than ore trucks would be expected to mobilize primarily road dust. In addition, naturally occurring dust (e.g., deflation from river deposits and cryogenically exposed soils) is likely to contribute additional $\mathrm{Al}$ and $\mathrm{Fe}$ to moss surfaces over time. Both of these processes infuse additional crustal elements into the environment that would effectively weaken the correlation between heavy metals and crustal elements. The relationship is likely to be further complicated by several factors. For example, generation of road dust may be minimal when the roadbed is frozen and/or snowcovered, but escapement from ore truck surfaces is presumably continuous throughout the year. Particle size and weight may also be important. The particle size of naturally occurring crustal elements is likely to be larger than the finely ground heavy metal concentrate, and therefore would not be expected to disperse as far. On the other hand, $\mathrm{Al}$ and $\mathrm{Fe}$ in the roadbed are probably crushed by the weight of passing vehicles into finer and lighter materials that may travel farther than might otherwise be expected. Regardless of these differences, the strength of the between-group correlations suggests that important depositional pathways are shared by road dust and ore concentrate. 


\subsection{Topography and wind as related to moss concentrations}

One of the prominent features depicted in conditional simulation maps (and confirmed by spatial regression analyses) is the difference between moss concentration patterns on the north and south side of the haul road (Figs. 4-6; Table 4). The physical barriers and transport pathways formed by various topographic features are consistent with these and other patterns. Seasonal winds from the west and south (Exponent, 2002a) are probably a contributing factor driving deposition north of the haul road. Local topography also appears to influence patterns of heavy metal deposition, constraining deposition to a narrower swath on the south vs. north side of the road. For example, immediately south of the haul road, airborne deposition is constrained by the Tahinichock Mountains (elevation 502 m, Fig. 1). Elevated metal levels encroach on the mid and upper slopes of the north-facing mountain slopes but decrease steadily over the crest to the south (Fig. 7). The result is the compressed depositional pattern observed $0-5 \mathrm{~km}$ south of the haul road corridor. Conversely, depositional intervals north of the haul road are noticeably broad (Figs. 4, 5 and 7). Lead deposition in the 10-20 $\mathrm{mg} / \mathrm{kg} \mathrm{dw}$ range is especially pronounced $4-30 \mathrm{~km}$ north of the haul road where the gently sloping terrain drains toward the Omikviorok River providing little topographic impediment to airborne contaminant movement (Fig. 7).

The interaction of wind and topography may also cause depositional fallout in certain areas. The Kisimilot/Iyikrok hills (north of the Wulik River, Fig. 1) are a possible example. Moss $\mathrm{Pb}$ concentrations are noticeably higher here than in the areas further north (Fig. 7-inset). This may reflect deposition of heavy metal-laden dust (mine-related and/or naturally derived) from a focusing effect such as pocket turbulence or the abruptly decreasing wind velocity due to contact with the intermittent topographic features formed by the Kisimilot/Iyikrok hills.

\subsection{Extent of depositional area}

In the absence of pre-mine baseline data, it is difficult to directly determine the actual extent of atmospheric deposition of heavy metals due to ore concentrate escapement in and around the Monument. Earlier work that covered a $1.6 \mathrm{~km}$ swath on either side of the haul road (Ford and Hasselbach, 2001) noted that moss concentrations of $\mathrm{Cd}, \mathrm{Pb}$, and $\mathrm{Zn}$ were still elevated at transect points furthest from the haul road relative to maximum concentrations previously reported from undisturbed sites in Arctic Alaska by Ford et al. (1995). In that study, application of enrichment factors (element to $\mathrm{Al}$ ratios in mosses vs. local soil parent material) that control for local geology also suggested that concentrate was still being deposited $1.6 \mathrm{~km}$ from the haul road. One of the purposes of the present research was to expand the spatial extent of the earlier studies to gain a clearer picture of the potential depositional area of ore concentrate.

One indication that the full areal extent of heavy metal deposition has been identified would be an obvious 'leveling-off' of moss concentrations at some distance from the haul road. This does not generally occur for $\mathrm{Cd}$ and $\mathrm{Pb}$ within the study area (Fig. 3a).

In the southern portion of the study area, moss concentrations of $\mathrm{Cd}$ are less than maximum values previously reported from Arctic Alaska by Ford et al. (1995) (Fig. 4; Table 5). In addition, moss Cd concentrations north of the haul road drop below maximum regional values reported by Ford et al. (1995) at a distance of approximately $12 \mathrm{~km}$ (Fig. 4; Table 5). Collectively, these findings suggest that moss concentrations of $\mathrm{Cd}$ are unaffected or only slightly affected by mining-related deposition beyond $3 \mathrm{~km}$ to the south and $12 \mathrm{~km}$ to the north of the haul road. In contrast, $\mathrm{Pb}$ levels in the northernmost part of the study area exceed both previously reported Arctic Alaskan maxima (Ford et al., 1995) and concentrations throughout the southernmost parts of the study area (Fig. 5; Table 5). In the Kisimilot/Iyikrok hills (north of the Wulik River, Fig. 1), moss Pb concentrations ranged from 7 to $42 \mathrm{mg} / \mathrm{kg} \mathrm{dw}(n=5)$, exceeding the maximum $\mathrm{Pb}$ value of $2.3 \mathrm{mg} / \mathrm{kg} \mathrm{dw}$ reported by Ford et al. (1995). This fact, combined with the strength of the road-related $\mathrm{Pb}$ gradient revealed by our analyses (Figs. 3 and 5 and Table 4), suggests that mining-related $\mathrm{Pb}$ deposition extends at least as far north as the Kisimilot/Iyikrok hills, $25 \mathrm{~km}$ from the haul road.

Interpretation of $\mathrm{Pb}$ patterns in this northernmost portion of the study is complicated by the geo- 
chemical makeup of the broader region. This seems especially true for the area north of the Kisimilot/ Iyikrok hills where $\mathrm{Pb}$ levels decrease to approximately $7 \mathrm{mg} / \mathrm{kg} \mathrm{dw}$ (Fig. 7-inset). Our results suggest that subsurface geochemistry at sampling points is not responsible for elevated moss concentrations of heavy metals (Fig. 3b). However, areas of natural $\mathrm{Pb} / \mathrm{Zn}$ mineralization are known to exist northwest and northeast of the mine site (Kelley and Hudson, 2003; Exponent, 2002b).

Due to the lack of a vascular system, mosses do not actively take up elements from substrate. Therefore, $\mathrm{Pb}$ levels reflect atmospheric deposition. Thus, higher $\mathrm{Pb}$ levels from mosses in the far northern portion of the study area may be attributable to (1) atmospheric deposition from mining-related activities (e.g., fugitive dust), (2) atmospheric deposition from weathering of naturally enriched $\mathrm{Pb} / \mathrm{Zn}$ surface deposits in the broader region, or (3) a combination of the two. Sampling intensity in the northernmost portion of the study area was relatively low, and as a result, the prediction standard error for this area was high (Figs. 5 and 7). Additional sampling, both within the far northern portion of the current study area and beyond the study area boundary to the north, is needed to better understand patterns and sources of heavy metal concentrations in this area.

Finally, our study was centered on National Park Service lands $50 \mathrm{~km}$ west of the actual mine site and was not designed to examine spatial patterns of heavy metal deposition in the vicinity of the mine itself which could be an important contributor to observed spatial patterns of heavy metal concentrations in $H$. splendens moss. Such research is necessary to clarify the patterns and sources of atmospheric heavy metal deposition in the region.

\section{Conclusions}

Atmospheric deposition of heavy metals from mining-related activities appears to occur throughout the northern half of Cape Krusenstern National Monument on both sides of the haul road. The depositional area appears to extend north of Monument boundaries to the Kisimilot/Iyikrok hills (north of the Wulik River) and possibly beyond, although more study is needed in this area. Heavy metal concentrations in H. splendens moss were correlated most strongly with (1) distance from the DMTS haul road and (2) escapement from the port site and were not related to subsurface geochemistry at the sampling points. Spatial patterns with respect to the mine site were not studied.

Highest concentrations of heavy metals in mosses were found within $10 \mathrm{~m}$ of the haul road. Concentrations in samples at $1-10 \mathrm{~m}$ from the haul road ranged from 6.9 to $24.3 \mathrm{mg} / \mathrm{kg} \mathrm{dw}$ for $\mathrm{Cd}$ and $271-$ $912 \mathrm{mg} / \mathrm{kg} \mathrm{dw}$ for $\mathrm{Pb}$. In addition, heavy metal concentrations around the port site boundary were relatively high, particularly to the immediate northeast of the facility. Heavy metal levels in this area appear to be linked to the port site itself where soil $\mathrm{Pb}$ levels in excess of $27,000 \mathrm{mg} / \mathrm{kg}$ were reported near port facility operational areas in 1996.

Heavy metal concentrations in moss diminish rapidly away from both the haul road and the port site. In general, heavy metal concentrations decrease more slowly on the north side of the haul road than on the south. This difference is probably driven by topography and wind patterns. Atmospheric deposition south of the haul road appears to be constrained by the Tahinichok Mountains which likely function as a wind-shadow thereby protecting the south side of the mountains from deposition related to the haul road. Heavy metal levels continue to diminish southward, reaching a lowpoint near the Igichuk Hills, 40 $\mathrm{km}$ from the haul road, where both $\mathrm{Cd}$ and $\mathrm{Pb}$ concentrations in moss are within ranges previously reported from other parts of Arctic Alaska.

Concentrations of $\mathrm{Cd}$ and $\mathrm{Pb}$ in the northernmost part of the study area are greater than those in the southernmost part. This difference does not appear to be attributable to local variations in subsurface geochemistry at the sample points. Cd levels appear to be unaffected or only slightly affected by miningrelated deposition at distances greater than $12 \mathrm{~km}$ north and $3 \mathrm{~km}$ south of the haul road. By contrast, $\mathrm{Pb}$ levels in moss remain elevated throughout the northern portion of the study area relative to values previously reported from Arctic Alaska. It appears as though mine-related $\mathrm{Pb}$ has been deposited in the vicinity of the Kisimilot/Iyikrok hills (north of the Wulik River), $25 \mathrm{~km}$ north of the haul road. Potential mechanisms contributing to this phenomenon include localized turbulence and topography, although inputs 
from natural sources in the broader region cannot be discounted.

For reasons that remain unclear, moss $\mathrm{Pb}$ concentrations north of the Kisimilot/Iyikrok hills remain somewhat elevated (ca. $7 \mathrm{mg} / \mathrm{kg} \mathrm{dw}$ ) relative to moss concentrations in other parts of Arctic Alaska. Higher $\mathrm{Pb}$ levels from mosses in the far northern portion of the study area may be attributable to (1) atmospheric deposition from miningrelated activities (e.g., fugitive dust), (2) atmospheric deposition from weathering of naturally enriched $\mathrm{Pb} /$ $\mathrm{Zn}$ surface deposits in the broader region, or (3) a combination of the two.

Distinguishing between these sources is important to gain a fuller understanding of the role of mining activities in landscape-scale dissemination of heavy metals. Finer scale sampling is needed to better understand potential patterns of heavy metal deposition north of the Wulik River. Additional study with regard to spatial relationships between moss concentrations and the mine site itself is also recommended.

\section{Acknowledgements}

This research was funded by the National Park Service and by Federal Aid in Wildlife Restoration to the Alaska Department of Fish and Game. We thank the following people for assistance with logistics, study design, field work, analysis and/or editing: Deborah Coffey, Joel Cusick, Doug and Jennifer Houston, Emily Jacklitch, John Martinisko, Bruce McCune, Trent McDonald, Pat Muir, Walter Neitlich, Karen Oakley, Jerry Post, Teck Cominco Alaska Incorporated, Robert Winfree, and Suzy Will-Wolf. Ikayuqtit team members provided useful reviews of this manuscript. Thanks also to anonymous reviewers. Special thanks to Lois Dalle-Molle, Tom Heinlein, Julie Hopkins, and the late Dave Spirtes for support in all phases of this research.

\section{References}

Aberg G, Steinnes E, Hjelmseth H. Source regions and atmospheric deposition of long-range transported $\mathrm{Pb}$ in Norway 1977-2000 using moss as indicator. International Symposium on Applied
Isotope Geochemistry, vol. 4. California, USA: Pacific Grove; 2001-06-25-06-29.

Akaike H. Information theory and an extension of the maximum likelihood principle. In: Perron BN, Csaki F, editors. 2nd International Symposium in Information Theory. Budapest: Akademial Kiodo; 1973. p. 207-61.

Berg T, Steinnes E. Use of mosses (Hylocomium splendens and Pleurozium schreberi) as biomonitors of heavy metal deposition: from relative to absolute deposition values. Environ Pollut 1997;98(1):61-71.

Berg T, Hjellbrekke A, Rühling Å., Steinnes E, Kubin E, Larsen $\mathrm{MM}$, et al. Absolution deposition maps of heavy metals for the Nordic countries based on moss surveys. Temnord 2003, vol. 505. Copenhagen, DK: Nordic Council of Ministers; 2003. 34 pp.

Berger JO, De Oliveira V, Sansó B. Objective Bayesian analysis of spatially correlated data. J Am Stat Assoc 2001;96:1361-74.

Cressie N. Statistics for spatial data. New York: John Wiley and Sons; 1993. $900 \mathrm{pp}$.

Crock JG, Gough LP, Mangis DR, Curry KL, Fey DL, Hageman $\mathrm{PL}$, et al. Element concentrations and trends for moss, lichen, and surface soils in and near Denali national park and preserve, Alaska, US. Geol Surv Open-file Rep 1992a;92-323. [148 pp].

Crock JG, Severson RC, Gough LP. Determining baselines and variability of elements in plants and soils near the Kenai national wildlife refuge, Alaska. Water Air Soil Pollut 1992b; 63:253-71.

Crock JG, Beck KA, Fey DL, Hageman PL, Papp CS, Peacock TR. Element concentrations and baselines for moss, lichen, spruce, and surface soils, in and near Wrangell-Saint Elias national park and preserve, Alaska US. Geol Surv Open-File Rep 1993:93-14. [98 pp].

De Oliveira V, Kedeem B, Short DA. Bayesian prediction of transformed Gaussian random fields. J Am Stat Assoc 1997;92:1422-33.

ESRI. Arcview spatial analyst. Redlands (CA): Environmental Systems Research Institute; 1996.

Exponent. History and Environmental Impacts of Delong Mountain Transportation System Port Site, Red Dog Operations, Alaska. Unpublished report. Document no. 8601997.001 03010801 SS30. Available from Exponent, 15375 30th Place, Suite 250, Bellevue (WA) 98007; 2001.

Exponent. Draft 2001 Fugitive Dust Report. DeLong Mountain Regional Transportation System, Alaska. Unpublished report. Prepared for Teck Cominco Alaska Inc. Document No. 8601997.00105010102 SS25. Available from Exponent, 15375 30th Place, Suite 250, Bellevue (WA) 98007; 2002a.

Exponent. Draft Fugitive Dust Background Document, DeLong Mountain Regional Transportation System, Alaska. Unpublished report. Prepared by Teck Cominco Alaska Inc. and Exponent. Document No. 8601997.001.03020502SS20. Available from Exponent, 15375 30th Place, Suite 250, Bellevue (WA) 98007 ; 2002b.

Exponent. Port Site Characterization Sampling and Analysis Plan, DeLong Mountain Regional Transportation System, Alaska. Unpublished report. Prepared for Teck Cominco Alaska Inc. Document No. 8601997.00112000702 SS07. Available from 
Exponent, 15375 30th Place, Suite 250, Bellevue (WA) 98007; $2002 \mathrm{c}$.

Ford, J, Hasselbach, L. Heavy metals in mosses and soils on six transects along the Red Dog Mine Haul Road, Alaska. NPS/AR/ NRTR-2001/38. Available from Western Arctic National Parklands, P.O. Box 1029, Kotzebue, Alaska 99752, USA; 2001.

Ford J, Landers D, Kugler D, Lasorsa B, Allen-Gil S, Crecelius E, et al. Inorganic contaminants in Arctic Alaskan ecosystems: long-range atmospheric transport or local point sources? Sci Total Environ 1995;160/161:323-35.

Garbarino JR, Snyder-Conn E, Leiker TJ, Hoffman GL. Contaminants in arctic snow collected over northwest Alaskan sea ice. Water Air Soil Pollut 2002;139:183-214.

Gelman A, Carlin JB, Stern HS, Rubin DB. Bayesian data analysis. London: Chapman and Hall; 1995. 526 pp.

Hasselbach, L, Ver Hoef, J, Ford, J, Neitlich, P, Crecelius, E, Berryman, et al. Spatial patterns of cadmium and lead deposition on and adjacent to National Park Service lands near Red Dog Mine, Alaska: NPS Final Report. NPS/AR/NRTR2004-45. Available from Western Arctic National Parklands, P.O. Box 1029, Kotzebue, Alaska 99752, USA; 2004.

Kelley K, Hudson T. The natural dispersal of metals to the environment in the Wulik River-Ikalukrok creek area, Western Brooks Range, Alaska. U S Geol Surv Fat Sheet; 2003:103-7.

Mardia KV, Marshall RJ. Maximum likelihood estimation of models for residual covariance in spatial regression. Biometrika 1984; $71: 135-46$.

Økland T, Økland RH, Steinnes E. Element concentrations in the boreal forest moss Hylocomium splendens: variation related to gradients in vegetation and local environmental factors. Plant Soil 1999;209:71-83.

Public Law 96-487. Alaska National Interest Lands Conservation Act-December 2, 1980, Stat. 2371; 1980.

Public Law 99-96. A Bill to Amend the Alaska Native Claims Settlement Act, (99th Congress)-September 25, 1985, Section 34; 1985 .

Ross HB. On the use of mosses Hylocomium splendens and Pleurozium schreberi for estimating atmospheric trace metal deposition. Water Air Soil Pollut 1990;50:63-76.

Rühling Å., Steinnes E. Atmospheric heavy metal deposition in Europe 1995-1996. NORD, vol. 98:15. Copenhagen: Nordic Council of Ministers; 1998.
Rühling Å., Tyler G. Sorption and retention of heavy metals in the woodland moss Hylocomium splendens (Hedw). Br Sch Oikos 1970;21:92-7.

Satterthwaite FF. Synthesis of variance. Psychometrika 1941; 6:309-16.

Shaole W, Zhao Y, Feng X, Wittmeier A. Application of inductively coupled plasma mass spectrometry for total metal determination in silicon-containing solid samples using the microwave-assisted nitric acid-hydrofluoric acid-hydrogen peroxide-boric acid digestion system. J Anal At Spectrom 1996;11(4):287-96.

Steinnes E. A critical evaluation of the use of naturally growing moss to monitor the deposition of atmospheric metals. Sci Total Environ 1995;160/161:243-9.

Steinnes E, Rambæk JP, Hanssen JE. Large scale multi-element survey of atmospheric deposition using naturally growing moss as biomonitor. Chemosphere 1992;25:735-52.

Steinnes E, Rühling A., Lippo H, Mäkinen A. Reference materials for large scale metal deposition surveys. Accredit Qual Assur 1997;2:243-9.

Ver Hoef JM, Cressie N. Spatial statistics: analysis of field experiments. In: Scheiner SM, Gurevitch J, editors. Design and analysis of ecological experiments. Second Edition. Oxford University Press; 2001. p. 289-307.

Ver Hoef JM, Cressie N, Fisher RN, Case TJ. Uncertainty and spatial linear models for ecological data. In: Hunsaker CT, Goodchild MF, Friedl MA, Case TJ, editors. Spatial uncertainty for ecology: implications for remote sensing and GIS applications. New York: Springer-Verlag; 2001. p. 214-37.

Viereck LA, Dyrness CT, Batten AR, Wenzlick KJ. The Alaska vegetation classification. General Technical Report \#PNWGTR-286. Portland (OR): USDA Forest Service Pacific Northwest Research Station; 1992.

Wiersma GB, Slaughter C, Hilgert J, McKee A, Halpern C. Reconnaissance of Noatak national preserve and biosphere reserve as a potential site for inclusion in the integrated global background monitoring network. US Man and the Biosphere Program, vol. VI. Springfield: National Technical Information Service; 1986. 84 pp.

Wilk MB, Gnanadesikan R. Probability plotting methods for the analysis of data. Biometrika 1968;55:1-17. 